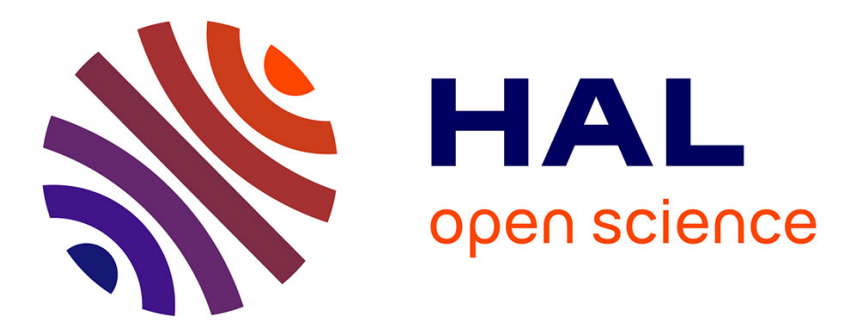

\title{
Removal of arsenate from drinking water with a natural manganese oxide in the presence of competing anions
}

\author{
Stéphanie Ouvrard, M.-O. Simonnot, M. Sardin
}

\section{To cite this version:}

Stéphanie Ouvrard, M.-O. Simonnot, M. Sardin. Removal of arsenate from drinking water with a natural manganese oxide in the presence of competing anions. Water Science and Technology: Water Supply, 2001, 1 (2), pp.167-173. 10.2166/ws.2001.0034 . hal-02445986

\author{
HAL Id: hal-02445986 \\ https://hal.science/hal-02445986
}

Submitted on 27 Jan 2020

HAL is a multi-disciplinary open access archive for the deposit and dissemination of scientific research documents, whether they are published or not. The documents may come from teaching and research institutions in France or abroad, or from public or private research centers.
L'archive ouverte pluridisciplinaire HAL, est destinée au dépôt et à la diffusion de documents scientifiques de niveau recherche, publiés ou non, émanant des établissements d'enseignement et de recherche français ou étrangers, des laboratoires publics ou privés. 


\title{
Removal of arsenate from drinking water with a natural manganese oxide in the presence of competing anions
}

\author{
S. Ouvrard*, M.-O. Simonnot*,** and M. Sardin* \\ *Laboratoire des Sciences du Génie Chimique, CNRS-ENSIC-INPL, 1 rue Grandville, BP 451, 54001 Nancy \\ Cedex, France \\ **Ecole Européenne d'Ingénieurs en Génie des Matériaux, INPL, 6 rue B. Lepage, BP 630, 54010 Nancy \\ Cedex, France
}

\begin{abstract}
The efficiency of arsenic removal from drinking water in adsorption processes using natural oxides may be influenced by the presence of other adsorbable anions. The present paper focuses on the study of arsenate adsorption by a natural manganese oxide. The objective is to determine which of the anions usually present in drinking water may be adsorbed: hydrogen carbonate, sulfate, chloride, nitrate, phosphate and arsenate. A kinetic batch experiment was conducted with a natural drinking water, leading to a first qualitative selection: nitrate and chloride little interact with the adsorbent, sulfate and hydrogen carbonate are adsorbed while phosphate and arsenate are strongly adsorbed. Then column experiments were run with aqueous solutions containing either chloride, sulfate etc. The previous trends were confirmed and the equilibrium isotherms of the adsorbable anions were built by integration of the breakthrough curves. The isotherms fitted with a Langmuir model showed that the capacities were low $\left(a\right.$ few $\left.\mu \mathrm{mol}^{-\mathrm{g}^{-1}}\right)$. The affinity order was determined from the isotherm initial slopes: arsenate >> phosphate > hydrogen carbonate $\cong$ sulfate. Given the strong affinity of the adsorbent for arsenate and the low arsenate concentration in drinking water, the process selectivity for As traces from drinking water is ensured.
\end{abstract}

\section{KEYWORDS}

Adsorption, arsenic, natural manganese oxide, trace element removal, water treatment

\section{INTRODUCTION}

Arsenic, a well-known toxic element, has been proved carcinogenic at low ingestion rate. Hence, its presence in drinking water even at low concentration is a threat for human health (Masud, 2000). As a result, the standards for arsenic in drinking water have been strongly reduced throughout the world, e.g. the EU critical concentration for arsenic in drinking water was lowered from 50 to $10 \mu \mathrm{g}$ As $\mathrm{L}^{-1}$ (EU 98/83/EC). Therefore, processes to selectively remove the excess arsenic from drinking water are urgently required. Fixed bed adsorption processes are well adapted to the selective elimination of trace elements. Several media are able to remove arsenic from water, particularly natural oxides (Pierce and Moore, 1982; Rosenblum and Clifford, 1984; Wilkie and Hering, 1996), which allow the oxidation of As III into As V and adsorb As V (arsenate). Among them, manganese oxide is often used (Scott and Morgan, 1995; Viraraghavan et. al, 1996). But phosphate ions may compete with arsenate ions for adsorption sites on many oxides (Manning and Goldberg, 1996; Ohki et. al, 1996) other anions, such as sulfate and hydrogen carbonate, may also have an influence on arsenate sorption processes. Therefore, the selective removal of arsenate from water is a multicomponent adsorption problem, and competition between arsenate and other anions should be taken into account.

This work was undertaken to study the efficacy of a fixed bed adsorption process using a natural manganese oxide as an adsorbent. Complementary methods were used under lab conditions to test the capacity of this sand to adsorb arsenate and the anions usually present in drinking waters: hydrogen carbonate, sulfate, chloride, phosphate and nitrate. Batch experiments using a natural drinking water were conducted to show the reactivity of the different species. Then, laboratory column experiments were run with aqueous solutions 
containing each element separately, in order to build the equilibrium adsorption isotherms and find the affinity order.

\section{MATERIALS AND METHODS}

\section{Adsorbent}

The natural manganese oxide contained about $71 \% \mathrm{w} . \mathrm{MnO}_{2}, 4 \% \mathrm{Fe}, 6 \% \mathrm{Al}_{2} \mathrm{O}_{3}$. It was a sandy material with a mean particle size of $600 \mu \mathrm{m}$ and a BET surface determined by $\mathrm{N}_{2}$ adsorption of $17 \mathrm{~m}^{2} \mathrm{~g}^{-1}$. The point of zero charge measured by potentiometric titration was 4.7. The sand was washed with deionized water without any further treatment.

\section{Solutions}

Solutions were either a natural drinking water (Table 1) or aqueous solutions prepared by dissolving salts $\left(\mathrm{NaCl}, \mathrm{KH}_{2} \mathrm{PO}_{4}-\mathrm{K}_{2} \mathrm{HPO}_{4}, \mathrm{Na}_{2} \mathrm{HAsO}_{4} \cdot 7 \mathrm{H}_{2} \mathrm{O}, \mathrm{Na}_{2} \mathrm{SO}_{4}, \mathrm{NaHCO}_{3}\right.$ ) into deionized water (Table 2).

Table 1. Composition of the natural drinking water (batch experiment)

\begin{tabular}{cccccccc}
\hline \multirow{2}{*}{$\mathrm{pH}$} & total cationic concentration & $\mathrm{Cl}^{-}$ & $\mathrm{NO}_{3}^{-}$ & $\mathrm{HCO}_{3}^{-}$ & $\mathrm{SO}_{4}^{2-}$ & $\mathrm{PO}_{4}$ & $\mathrm{HAsO}_{4}^{-}$ \\
\cline { 2 - 7 } & $\mathrm{meq} / \mathrm{L}$ & $\mathrm{mM}$ & $\mathrm{mM}$ & $\mathrm{mM}$ & $\mathrm{mM}$ & $\mu \mathrm{M}$ & $\mu \mathrm{M}$ \\
\hline 7.0 & 1.960 & 0.341 & 0.105 & 1.344 & 0.081 & 5.79 & 0.374 \\
\hline
\end{tabular}

Table 2. Composition of the feed solutions (column experiments)

\begin{tabular}{ccc}
\hline salt & concentration range & $\mathrm{pH}$ \\
\hline $\mathrm{Na}_{2} \mathrm{HAsO}_{4} \cdot 7 \mathrm{H}_{2} \mathrm{O}$ & $0.5-1300 \mu \mathrm{mol} . \mathrm{L}^{-1}$ & $7.1-7.9$ \\
$\mathrm{KH}_{2} \mathrm{PO}_{4}-\mathrm{K}_{2} \mathrm{HPO}_{4}$ & $470-4800 \mu \mathrm{mol} . \mathrm{L}^{-1}$ & $6.5-6.9$ \\
$\mathrm{NaHCO}_{3}$ & $1.1-42 \mathrm{mmol} . \mathrm{L}^{-1}$ & $7.1-7.5$ \\
$\mathrm{Na}_{2} \mathrm{SO}_{4}$ & $1-50 \mathrm{mmol} . \mathrm{L}^{-1}$ & $5.0-6.7$ \\
$\mathrm{NaNO}_{3}$ & $1-100 \mathrm{mmol} . \mathrm{L}^{-1}$ & $5.2-5.4$ \\
$\mathrm{NaCl}$ & $1-100 \mathrm{mmol} . \mathrm{L}^{-1}$ & $5.2-5.4$ \\
\hline
\end{tabular}

\section{Batch experiments}

Suspensions ( $1 \mathrm{~g}$ sand $-100 \mathrm{~mL}$ natural water) were allowed to equilibrate in batch reactors. Anion concentrations were measured as a function of time. Anion analyses were performed on a Dionex $4000 \mathrm{I}$ ion chromatograph.

\section{Column experiments}

They were run by feeding a column $\left(10 \mathrm{~g}\right.$ adsorbent, $5 \mathrm{~mL}$, i.d.: $1 \mathrm{~cm}$, flow rate: $\left.25 \mathrm{~mL} . \mathrm{h}^{-1}\right)$ with an aqueous solution containing a single anionic element at the concentration $\mathrm{C}_{0}$, until this inlet concentration was 
reached in the effluent. Experiments were repeated at different $\mathrm{C}_{0}$. The investigated concentration ranges (Table 2) were chosen from the usual concentrations in natural drinking waters: hydrogen carbonate and sulfate are major species (up to a few hundreds $\mathrm{mg} \mathrm{L}^{-1}$ ), while phosphorous and arsenic may be present respectively as minor and trace elements (up to resp. a few ppm and a few tens ppb). The breakthrough curves (BTCs) were measured by on line conductimetry. It had been previously checked that the BTCs obtained by this method were identical with the ones determined by anion analyses after fraction collection. The direct measurement has the advantage to be fast and simple. The $\mathrm{pH}$ was also measured on line at the column outlet. Since the feeding solution must contain only one anionic element, the $\mathrm{pH}$ value was not controlled by an external $\mathrm{pH}$ buffer. Therefore the $\mathrm{pH}$ feeding value was between 5 and 8 (Table 2).

\section{Tracing experiments}

They were run with a toluene aqueous solution. Toluene was chosen as a water tracer (concentration: 259 $\mathrm{mg} . \mathrm{L}^{-1}$ in deionized water) since it was assumed to be an inert species providing the adsorbent contained no organic carbon. It was detected at the column outlet by on-line UV spectrophotometry, at $261 \mathrm{~nm}$.

\section{Isotherm determination}

Isotherms were built from the BTCs. For a given element, each equilibrium point $\left(\mathrm{C}_{0}, \mathrm{q}_{0}\right)$ is obtained by integrating the area between the BTC measured at the feeding concentration $\mathrm{C}_{0}$ and the tracer BTC. The whole isotherm is then determined from the set of BTCs obtained at different $\mathrm{C}_{0}$. This dynamic method is very effective and accurate (Sardin and Schweich, 1981). Especially in the present case, with a low capacity adsorbent, it is well adapted. As a matter of fact, the conventional batch method is difficult to run because the differences between initial and final concentrations in the aqueous phase may be very small, which increases uncertainties.

\section{RESULTS AND DISCUSSION}

\section{Batch experiments}

The kinetic curves showed that equilibrium was reached within $1500 \mathrm{~min}$, i.e. $24 \mathrm{~h}$ (Figure 1). Arsenate and phosphate concentrations sharply dropped to zero. Nitrate and chloride concentrations remained unchanged. Sulfate concentration increased by a factor of about two, showing that sulfate anions were initially present at the adsorbent surface. Hydrogen carbonate concentration was not measured but deduced from the other ones assuming electroneutrality. It slightly decreased to reach $0.85 \mathrm{C}_{0}$. Therefore:

1. chloride and nitrate may not interact with the adsorbent,

2. hydrogen carbonate and sulfate are adsorbed,

3. phosphate and arsenate probably have a strong affinity for the adsorbent.

No quantitative conclusion can be given at this point.

\section{Column experiments}

Breakthrough curve analysis. The tracer breakthrough curve location gives the total porosity accessible to the water: $\varepsilon=0.60$ (Figure 2). This rather high value indicates the existence of an internal porosity. A complementary measurement was done at high flow rate $\left(400 \mathrm{~mL} \mathrm{~h}^{-1}\right)$, assuming that only the external porosity is accessible to the water. The obtained external porosity was $\varepsilon_{\mathrm{e}}=0.50$, then the internal porosity $\varepsilon_{\mathrm{i}}$ $=0.20$, knowing that $\varepsilon=\varepsilon_{\mathrm{e}}+\left(1-\varepsilon_{\mathrm{e}}\right) \varepsilon_{\mathrm{i}}$. The Peclet number deduced from the tracer curve was 10 . This value is correlated with the low column length.

Chloride and nitrate BTCs are identical whatever the feeding concentration and are superimposed with the tracer BTC (Figure 2). This behavior clearly shows that chloride and nitrate are inert species towards the adsorbent. They can be used as water tracers for further experiments. 


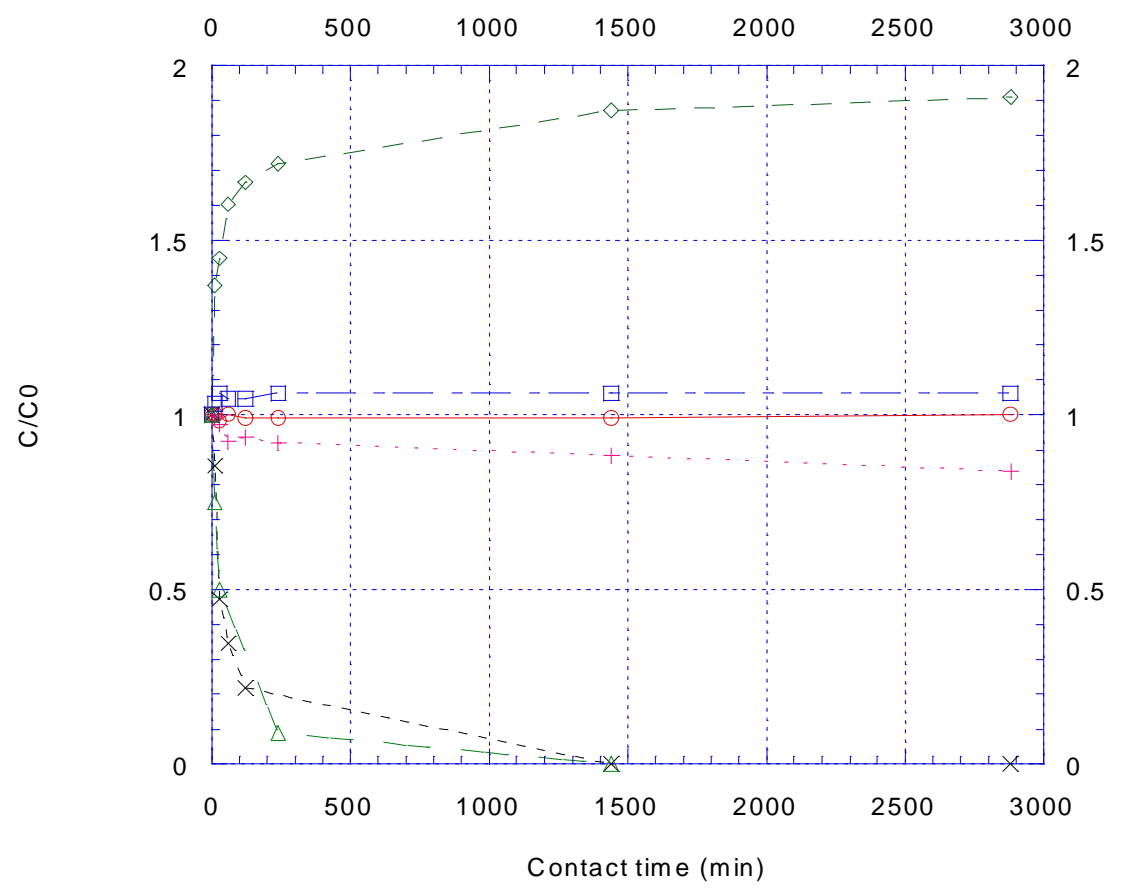

Figure 1. Concentration of chloride $(0)$, nitrate $(\square)$, sulfate $(\diamond)$, total phosphate $(\times)$, hydrogen carbonate $(+)$ and arsenate $(\Delta)$ as a function of time, after addition of $1 \mathrm{~g}$ sand to $100 \mathrm{~mL}$ natural water (Table 1 )

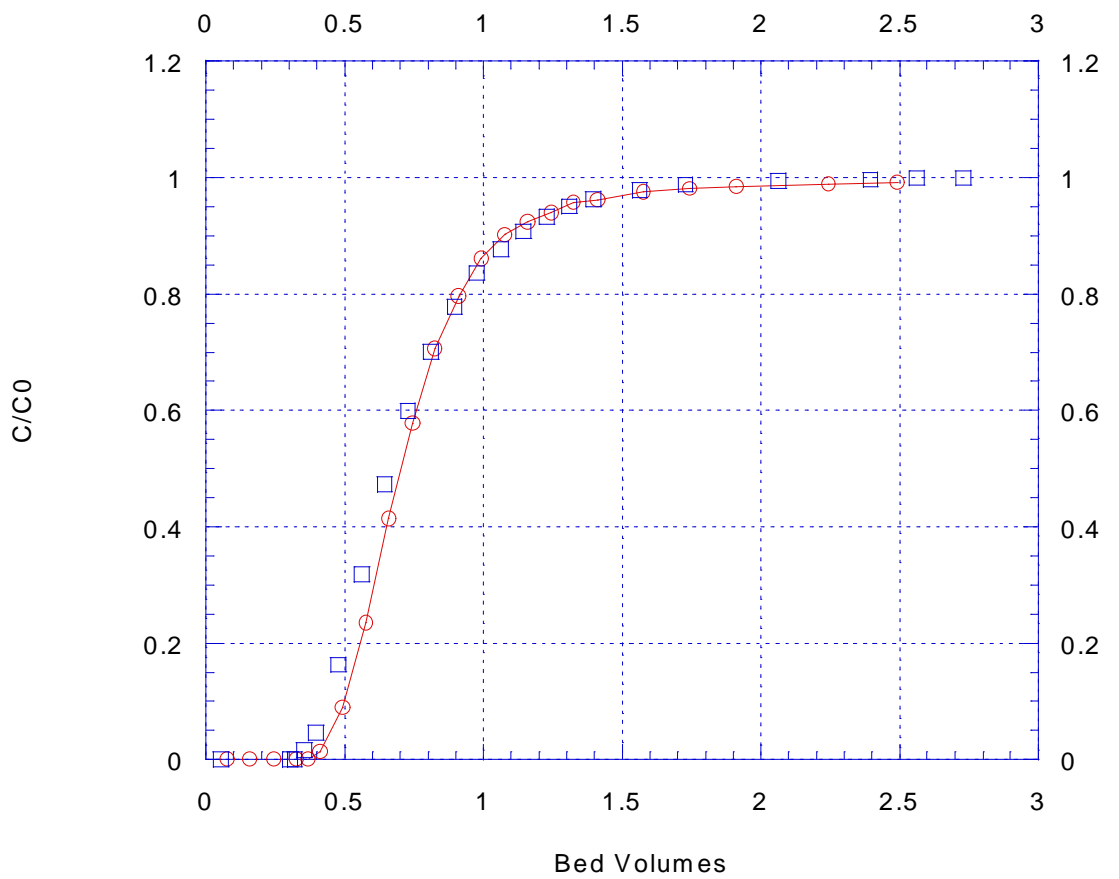

Figure 2. Toluene BTC (column fed at $\mathrm{C}_{0}=259 \mathrm{mg} / \mathrm{L}$ ) compared to chloride (o) and nitrate ( $\square$ ) BTCs (column fed at $\mathrm{C}_{0}=0.001 \mathrm{M}$ ) 
Sulfate and hydrogen carbonate are retarded compared to the tracer as plotted in Figure 3a. Phosphate (Figure $3 \mathrm{a}$ and $\mathrm{b}$ ) and arsenate (Figure $3 \mathrm{~b}$ ) are still more retarded, but comparing these two elements with the other ones is difficult because of the very different concentration range. Tailing appears at high feeding concentration but all the BTCs finally reach the horizontal line $\mathrm{C} / \mathrm{C}_{0}=1$, and the whole area was taken into account in the integration.

Reversibility of adsorption was checked. At the end of an adsorption experiment, if the column was fed with water, the adsorbed anion was desorbed and the released amount equaled the adsorbed one. If desorption was run one or two days later, the concentration on the desorption plateau might be slightly lower than on the adsorption plateau, probably because of internal mass transfer limitations. But this effect was very slight (a few \% decrease). Anyway, the objective of this study was not to measure column aging, but really to work at the time scale of a treatment process, the order of magnitude of the contact time being a few minutes. In these conditions, adsorption is reversible.

(a)

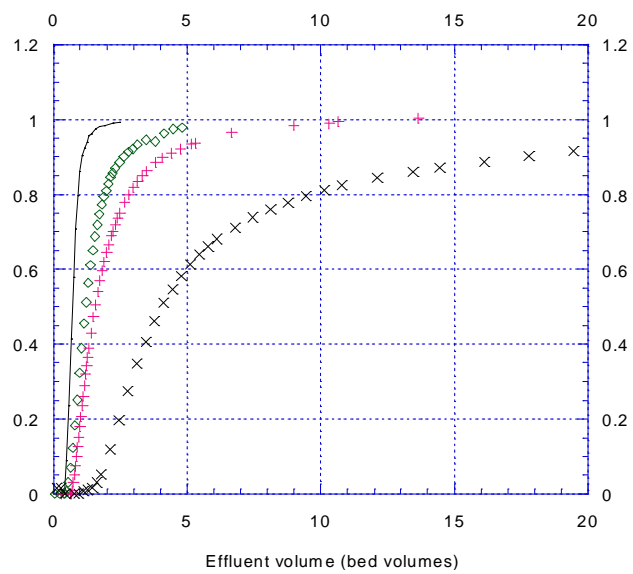

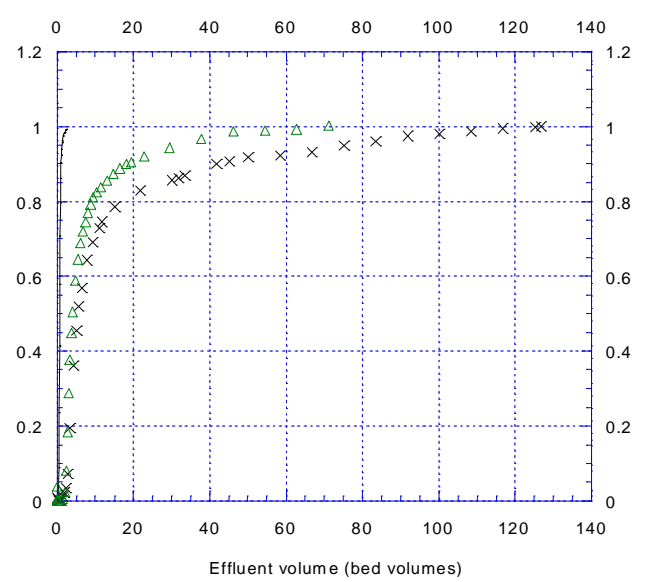

Figure 3. Breakthrough curves of tracer $(-)$, sulfate $(\diamond)$, carbonate $(+)$ and phosphate $(\times)$ for a 0 to $0.001 \mathrm{M}$ concentration step (a) and phosphate $(\times)$ and arsenate $(\Delta)$ for a 0 to $50 \mathrm{ppm}$ concentration step (b)

Equilibrium isotherms. Comparison of the equilibrium isotherms is given in Figure 4. Figure 5 focuses on the lowest concentration range. The isotherms were fitted with the Langmuir model: $q=\frac{K_{L} q_{\max } C}{1+K_{L} C}$, with q,

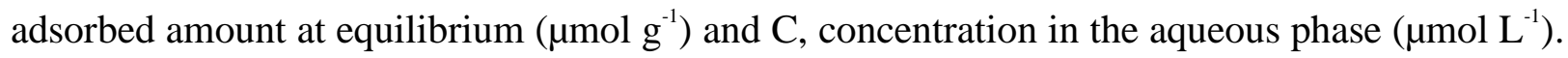

This model was used, as frequently done, for a mathematical fitting of the isotherm shape, without taking into account the basic Langmuir assumptions. Parameters (Table 3) were determined by direct optimization with a least-square method (Kaleidagraph package).

The affinity order deduced from the isotherm initial slopes (products $\mathrm{K}_{\mathrm{L}} \mathrm{q}_{\max }$ ) is: arsenate $>$ phosphate > sulfate $\approx$ hydrogen carbonate. Arsenate is the most preferred anion, what confirms the potential of the studied adsorbent to remove arsenic traces from water.

The feeding solutions were at $\mathrm{pH} 5$ to 8 , and the effect of $\mathrm{pH}$ on the affinity order must be discussed. $\mathrm{pH}$ has an influence on the surface charge and on the dissociation reactions in the aqueous phase: arsenate is in the form $\mathrm{H}_{2} \mathrm{AsO}_{4}{ }^{-} / \mathrm{HAsO}_{4}{ }^{2-}$ in the same way as phosphate $\mathrm{H}_{2} \mathrm{PO}_{4}{ }^{-} / \mathrm{HPO}_{4}{ }^{2-}\left(\mathrm{pK}\right.$ resp. 6.77 and 7.21 at $25^{\circ} \mathrm{C}$ ), sulfate is divalent and hydrogen carbonate mainly monovalent ( $\left.\mathrm{pK} \mathrm{HCO}_{3} / \mathrm{CO}_{3}{ }^{2-}=10.25\right)$. At $\mathrm{pH} 7$, sulfate would be less adsorbed than at $\mathrm{pH} 5-6$, since the adsorbent surface charge would be higher and the electrostatic repulsion of divalent anions would be enhanced. Arsenate would be more adsorbed at $\mathrm{pH} 7$ than at $\mathrm{pH} 7.1$ to 7.9 , since the surface will be less negatively charged and the ratio $\left[\mathrm{HAsO}_{4}{ }^{2-}\right] /\left[\mathrm{H}_{2} \mathrm{AsO}_{4}{ }^{-}\right]$would be lower: 1.70 at $\mathrm{pH} 7 ; 2.14$ at 7.1 and 13.5 at 7.9. Therefore if all the solutions were at $\mathrm{pH} 7$, the affinity order would not be changed. 


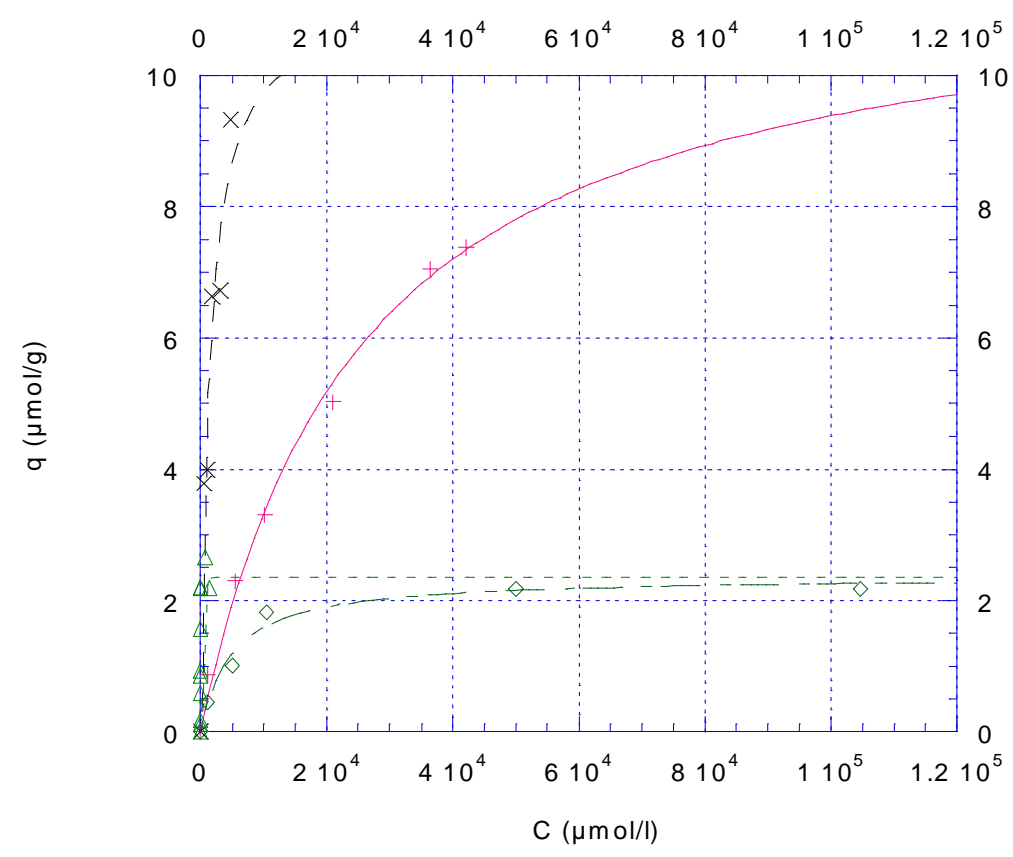

Figure 4. Adsorption isotherms $\left(20^{\circ} \mathrm{C}\right)$ of phosphate $(\times)$, bicarbonate $(+)$, arsenate $(\Delta)$ and sulfate $(\diamond)$

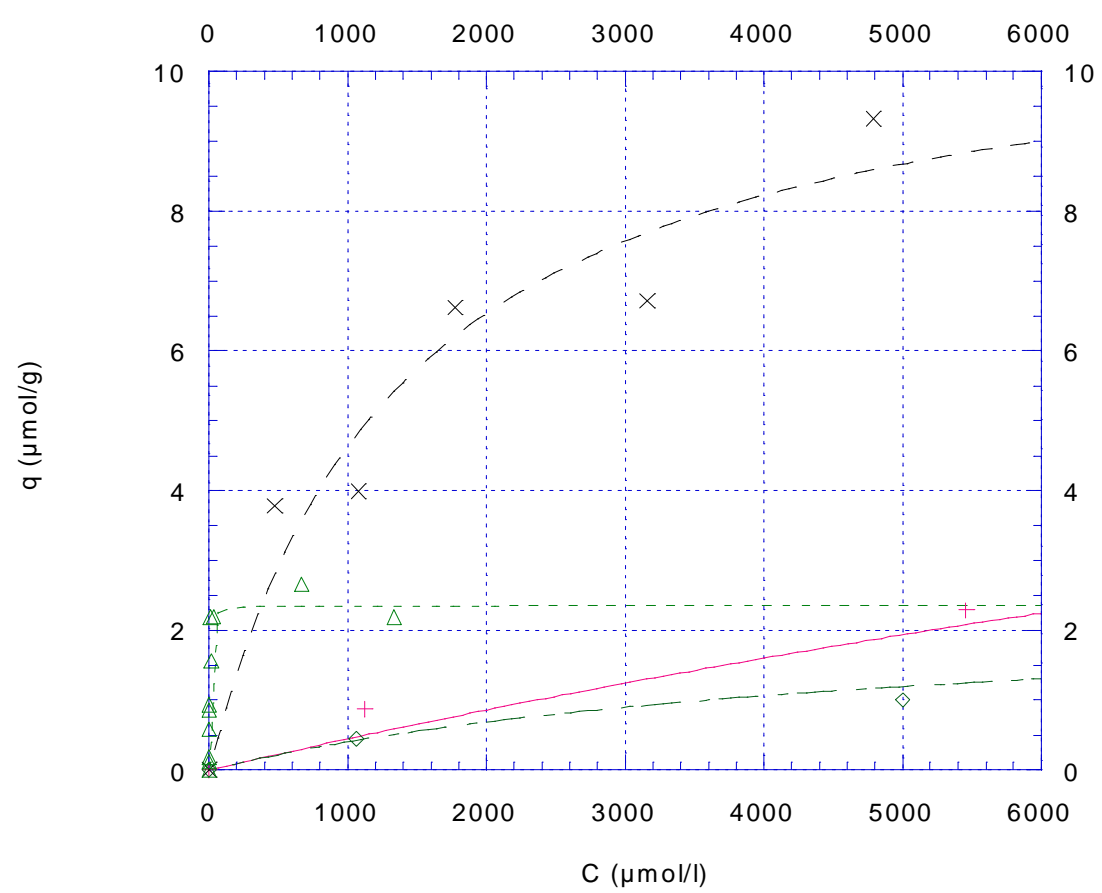

Figure 5. Zoom at small concentrations of the adsorption isotherms $\left(20^{\circ} \mathrm{C}\right)$ of phosphate $(\times)$, bicarbonate $(+)$, arsenate $(\Delta)$ and sulfate $(\diamond)$ 
Table 3. Langmuir coefficients for adsorption isotherms of arsenate, phosphate, sulfate and bicarbonate

\begin{tabular}{|c|c|c|c|}
\hline Anions & $\mathrm{q}_{\max }\left(\mu \mathrm{mol} \cdot \mathrm{g}^{-1}\right)$ & $\mathrm{K}_{\mathrm{L}}\left(\mathrm{L} \cdot \mu \mathrm{mol}^{-1}\right)$ & $\mathrm{K}_{\mathrm{L}} \mathrm{q}_{\max }\left(\mathrm{L} \cdot \mathrm{g}^{-1}\right)$ \\
\hline Arsenate & 2.35 & 0.35 & 0.823 \\
\hline Phosphate & 11.1 & $7.110^{-4}$ & $7.88 \quad 10^{-3}$ \\
\hline Sulfate & 2.36 & $2.010^{-4}$ & $4.7210^{-4}$ \\
\hline Bicarbonate & 11.8 & $3.910^{-5}$ & $4.6010^{-4}$ \\
\hline
\end{tabular}

Anions can be ranked in two groups according to the maximal capacity values:

1. arsenate and sulfate: maximal capacity $2.35 \mu \mathrm{mol} \mathrm{g}{ }^{-1}$,

2. phosphate and hydrogen carbonate: maximal capacity between 11 and $12 \mu \mathrm{mol} \mathrm{g}$.

Arsenate and phosphate are not in the same group, showing that the difference in capacity is not due to the affinity order, nor to the concentration range. This distinction is not due to the valence, nor to the occurring of dissociation reactions. It may be due to the existence of two types of adsorption sites but there is no evidence for the moment.

Multicomponent adsorption is not the sum of monocomponent adsorptions because of the interactions between the adsorbable species, and the operating capacity of the adsorbent cannot be directly deduced from individual isotherms. Nevertheless, isotherm parameters allow the computation of the amounts of each individual anion of the drinking water that would be adsorbed if no competition occurred i.e. from monocomponent feeding solutions (Table 4).

The results give some trends:

1. hydrogen carbonate and arsenate are the major adsorbed species, the former since it is predominant in water, the latter since it is the most preferred species,

2. the total adsorbed amount is lower than the maximal capacities, and it would still be true if hydrogen carbonate concentration was doubled.

Thus a water treatment process with this adsorbent would give good results in terms of arsenate elimination for different water compositions.

Table 4. Computation of the amounts that would be adsorbed from individual solutions, each anion concentration being the same as in the natural drinking water.

\begin{tabular}{ccc}
\hline Anion & Concentration $(\mu \mathrm{M})$ & Adsorbed amount $\left.(\mu \mathrm{mol} \mathrm{g})^{-1}\right)$ \\
\hline $\mathrm{Cl}^{-}$ & 341 & 0 \\
$\mathrm{NO}_{3}^{-}$ & 105 & 0 \\
$\mathrm{HCO}_{3}^{-}$ & 1344 & 0.587 \\
$\mathrm{SO}_{4}^{2-}$ & 81 & 0.038 \\
total $\mathrm{PO}_{4}$ & 5.79 & 0.046 \\
total As & 0.374 & 0.272 \\
Total & & 0.943 \\
\hline
\end{tabular}




\section{CONCLUSION}

In conclusion, the natural manganese oxide sand is able to adsorb different anions occurring in drinking water: hydrogen carbonate, sulfate, phosphate and arsenate. The affinity order deduced from monocomponent adsorption experiment is: arsenate $>>$ phosphate $>$ sulfate $\approx$ hydrogen carbonate. A competition may occur between arsenate and phosphate for the adsorbing sites.

Therefore, a drinking water treatment process using this adsorbent selectively removes arsenic traces because of the strong affinity of arsenate coupled with the very low arsenate concentration in water. Different drinking water composition can be treated, provided phosphate concentration is low, which is generally true.

The present study was focused on the behavior of individual anions towards the adsorbent. It must be extended by a study of arsenate - phosphate competition, this work is in progress.

The characterization of the key-mechanisms and the measurement of the adsorption constants will allow to develop a model of the process, which will be helpful to quickly determine the feasibility of the removal for any drinking water

\section{REFERENCES}

Council Directive 98/83/EC of 3 November 1998 on the quality of water intended for human consumption. (1998). Off. J. Eur. Communities, L, Legis., 330, 32-54.

Masud K. (2000). Arsenic in groundwater and health problems in Bangladesh. Water Res., 34, 304-310.

Manning B.A. and Goldberg S. (1996). Modeling competitive adsorption of arsenate with phosphate and molybdate on oxide minerals. Soil Sci. Soc. Am. J., 60, 121-131.

Ohki A., Nakayachigo K., Naka K. and Maeda S. (1996). Adsorption of inorganic and organic arsenic compounds by aluminum-loaded coral limestone. Appl. Organomet. Chem., 10, 747-752.

Pierce M.L. and Moore C.B. (1982). Adsorption of arsenite and arsenate on amorphous iron hydroxide. Water Res., 16, 1247-1253.

Rosenblum E. and Clifford D. (1984). The equilibrium arsenic capacity of activated alumina. Project Summary EPA. 600/S, 83-107

Schweich D. and Sardin M. (1981). Adsorption, partition, ion exchange and chemical reaction in batch reactors and in columns: a review. J. Hydrol., 50, 1-33

Scott M.J. and Morgan J.J. (1995). Reaction at oxide surfaces. 1. Oxidation of As(III) by synthetic birnessite. Environ. Sci. Technol., 29, 1898-1905.

Viraraghavan T., Subramanian K.S. and Tanjore S. (1996). Removal of arsenic in drinking water by manganese greensand filtration, oxide-coated sand filtration and ion-exchange treatment. Adv. Filtr. Sep. Technol., 10, 502-507.

Wilkie J.A. and Hering J.G. (1996). Adsorption of arsenic onto hydrous ferric oxide: effects of adsorbate/adsorbent ratios and co-occurring solutes. Colloids Surf., 107, 97-110. 